\title{
Diet selection by sheep and goats on Mediterranean heath- woodland range
}

\author{
J. BARTOLOME, J. FRANCH, J. PLAIXATS, AND N.G. SELIGMAN
}

Authors are Unitat d'Ecologia, Departament de Biologia Animal, Biologia Vegetal i Ecologia, Universitat Autònoma de Barcelona. 08193 Bellaterra, España; Departament de Patologia i Producció Animals and Agricultural Research, Facultat de Veterinària, Universitat Autdnoma de Barcelona, 08193 Bellaterra, España; and Agricultura Research Organization, Volcani Center, Bet Dagan 50 250, Israel.

Abstract

The study determined the species components of the diets of small ruminants grazing mountain ranges of the Montseny Biosphere Reserve (Catalunya, NE Spain). Three mixed flocks of sheep and goats, led by shepherds, were monitored for a year. Animals grazed a mountain rangeland composed of Quercus ilex woodland and Calluna-Erica heathland during the day and were returned to their corrals every night. Diet selection was estimated using fecal analysis. Of the 111 species that were identified, 71 were common to both sheep and goat. Of these, 23 were represented in proportions of more than $1 \%$ of the annual diet. Even though goats and sheep grazed together, their diets were significantly different $(p<0.0001$ ), the animal factor accounting for $18 \%$ to $60 \%$ of the total variation among the main diet components. Variation between seasons was also a major (5\% to $56 \%$ ) highly significant factor, while differences between flocks accounted for a significant, but relatively small part (3\% to 10\%) of the total variation in diet. The outstanding difference was the avoidance of the tree, Quercus ilex, by the sheep while the goats selected it throughout the year. Sheep selected graminoids throughout the year while goats tended to avoid them. For the rest there was substantial overlap in species composition between the diet of sheep and goats, especially when analysed over an entire cycle.

Key Words: Calluna vulgaris, Erica arborea, fecal analysis, microhistological analysis, Quercus ilex

Interspecific dietary differences between sheep and goats on Mediterranean landscapes have been described in several studies (Cuartas and García-González 1992, Leoufre et al. 1989). In general, goats tend to graze higher vegetation strata than sheep (Pfister et al. 1988, Illius and Gordon 1990). This propensity could have been acquired by selection during domestication because wild goats show no such preference for woody species (Cuartas 1992). Foraging preferences can also reflect regionally determined feeding experience handed down by mothering (Provenza 1994). Goats from different regions when grazing together select different species from a herbaceous sward (Fedele et al. 1993). Different sheep breeds have different foraging habits

\footnotetext{
Valuable comments by D.R. Garcia-Gonzalez. Pyrenee Ecological Institute, Jaca, to an earlier draft of this paper are gratefully acknowledged. Manuscript accepted 3 Nov. 1997.
}

\section{Resumen}

El objetivo de este trabajo fué determinar la composición específica de las dietas de pequeños rumiantes que pastorean en las montañas de la Reserva de la Biosfera del Montseny (Catalunya, NE España). Durante un año se estudiaron tres rebaños mixtos de ovejas y cabras, conducidos por pastores. Estos rebaños pastoreaban durante el dia en encinares de montaña de Quercus ilex y en landas de Calluna-Erica y cada noche volvian a su corral. La selección de la dieta se estimó a partir del análisis fecal. De las 111 especies identificadas, 71 resultaron comunes en ovejas y cabras, y 23 aparecieron en proporciones superiores al $1 \%$ de la dieta total anual. A pesar de que ovejas y cabras pastoreaban juntas, sus dietas fueron significativamente diferentes $(p<0.0001)$. El factor animal contribuyó en un 18 a $60 \%$ del total de la varianza entre los principales componentes de la dieta. La varianza entre estaciones fué tambien un factor altamente significativo ( $5 \%$ a $56 \%$ ), mientras que las diferencias entre rebaños contribuyeron en una pequeña parte, aún significutiva $(3 \%$ a $10 \%)$ del total de la varianza en la dieta. La principal diferencia fué el rechazo de la encina por parte de las ovejas en comparación con las cabras que la consumen durante todo el año. Las ovejas en cambio seleccionan especies graminoides a lo largo del año mientras las cabras tienden a rechazarlas. Para el resto de los componentes se observó un solapamiento sustancial en la composición especifica de la dieta de ovejas y cabras, especialmente al considerar globalmente el ciclo anual.

(Pfister et al. 1988, Warren et al. 1984) even though their nutritional requirements and digestive systems are very similar. As a result of different foraging styles, learned perception, and prehensile capabilities, diet selection is likely to differ between sheep and goats. However, the diets need not necessarily be very different nutritionally (Pfister and Malachek 1984, Wilson et al. 1975). There appears to be a trade-off between the extra handling time and the higher quality required to browse less accessible forage. These, and other, trade-offs give considerable 'elasticity' to most foraging constraints (Owen-Smith 1994). Furthermore, nutrient content in green leaves of most browse and forage species varies little. Consequently, different diets can be selected that meet the requirements of both animal species equally well.

Among the many possible combinations of species and plant parts with similar forage value, a ruminant foraging in a heterogeneous mixed species pasture must make many thousands of 
choices every day (Illius and Gordon 1990), often between forage items of poor to moderate quality. Unless the ruminant suffers from a deficiency that causes a specific hunger, like sodium (Belovsky 1981), day-to-day criterion, or rule, for selection of sufficient food for satisfaction of nutritional requirements must of necessity be simple, reliable, robust, and applicable to most vegetation types.

This study was undertaken to determine botanical composition of the diets of domestic sheep and goats grazing a Mediterranean woodland and an adjacent shrubby Atlantic heathland. The objective was not only to give a detailed comparative description of goat and sheep diets in the study region but also to identify, over an annual cycle, the role of animal species, season, and site in determining diet selection by small ruminant herds managed in the traditional manner by local shepherds. This information is necessary to assess the environmental impact of current changes in animal husbandry practices following depopulation of rural areas and the consequent encroachment of scrub onto pastures.

\section{Materials and Methods}

\section{Study Area}

The experimental area was situated in the Montseny Biosphere Reserve in Catalunya, Spain, Long. $2^{\circ} 18^{\prime}$ to $2^{\circ} 22^{\prime}$, Lat. $41^{\circ} 44^{\prime}$ to $41^{\circ} 47^{\prime}$, altitude between $700 \mathrm{~m}$ and $1,300 \mathrm{~m}$. The area has a humid Mediterranean climate with average rainfall varying between 800 and $1,000 \mathrm{~mm}$, peaking mainly in the spring and in the autumn. Summers are hot and relatively dry (Fig. 1). The landscape is mountainous with Holm oak (Quercus ilex L. ssp ilex) woodland on the slopes at altitudes between $700 \mathrm{~m}$ and $1,100 \mathrm{~m}$, and heartlands on analtiplano (La Calma) at altitudes between 1,100 and 1,300 m. The woodland, Quercetum mediterraneo-montanum (Bolòs 1983) was coppiced heavily until about 30 years ago, but much less since then. The canopy cover is almost continuous, but understory vegetation is relatively sparse and composed of shrubs and perennial forbs and grasses (mainly Erica arborea L. and Festuca spp.) Heath vegetation on the altiplano is composed of varying combinations of 3 physiognomic sub-groups of 2 plant communities: Calluna vulgaris heath and Erica scoparia-Cytisus scoparius heath, (both of the CallunoUlicetalia community) and Festuca-Trifolium-Agrostis tenuis grasslands of the Festuco-Brometea community (Bolòs 1983).

This study was conducted on the rangeland of 3 separate farms (Boscàs, Cortada and Molar), all situated within the Biosphere Reserve. Range area of each farm varied between 245 and 703 ha (Table 1).

\section{Botanical Composition of the Vegetation}

Distribution of the major species in the respective rangeland units was determined in the late spring (June-July) by measuring the cover of all species along 36 transects placed in representative sites. Of these, 27 line intercept transects ( 9 transects/farm), each $60 \mathrm{~m}$ long, were in the very heterogeneous woodland habitats where cover of all species below $1.3 \mathrm{~m}$ above ground level was recorded, and 9 line point transects ( 3 transects/farm), each $30 \mathrm{~m}$ long, were placed in the more homogeneous heath sites. All species encountered by a vertical needle, placed every $10 \mathrm{~cm}$, were recorded along the line point transects.
Table 1. Range characteristics and animal numbers on the experimental sites.

\begin{tabular}{|c|c|c|c|}
\hline & \multicolumn{3}{|c|}{ Flock } \\
\hline & Boscàs & Cortada & Molar \\
\hline & \multicolumn{3}{|c|}{$\ldots \ldots-\ldots$ (ha) $\ldots \ldots$} \\
\hline Total range area & 245 & 570 & 703 \\
\hline Vegetation types & \multicolumn{3}{|c|}{$-\ldots-\ldots(\%)-\ldots,-[$} \\
\hline Festuco-Brometea (grassland) & 5 & 1 & 1 \\
\hline Calluno-Ulicetalia (heathland) & 24 & 16 & 34 \\
\hline $\begin{array}{l}\text { Quercetum mediterraneo-montanum } \\
\text { (woodland) }\end{array}$ & 57 & 79 & 63 \\
\hline Crops and sown pastures & 14 & 4 & 2 \\
\hline Livestock & \multicolumn{3}{|c|}{$\ldots \ldots \ldots$ (numbers) $\ldots \ldots \ldots$} \\
\hline Sheep & 160 & 200 & 160 \\
\hline Goats & 50 & 70 & 100 \\
\hline & \multicolumn{3}{|c|}{$\ldots \ldots$ (animals/ha) $\ldots \ldots \ldots$} \\
\hline Stocking rate & 0.86 & 0.47 & 0.37 \\
\hline
\end{tabular}

${ }^{1} \%$ of total rangeland area determined from aerial photographs.

\section{Livestock Management}

Three different flocks of sheep and goats were studied (Table 1). Each flock grazed the rangeland unit of the respective farms. There were only these 3 mixed flocks on this area. The livestock were commercial Ripollesa sheep (45 to $65 \mathrm{~kg}$ adult live weight) and Murciana goats (40 to $50 \mathrm{~kg}$ adult live weight). They were always herded by a shepherd, and were returned to home corrals every evening except during the summer months (July to midOctober) when they were corralled on the altiplano. As a rule, the flocks were taken through the woodlands up to the altiplano in the morning and down again in the afternoon, when they would be allowed to graze crop residues on the crop area, and in some cases, to graze a rationed area of sown ryegrass pasture for up to 1 hour during the winter months. Adult animals were given a mineral supplement of salt, calcium, and phosphorus during most of the year and hay only when snow prevented grazing (Bartolomé and Franch 1992).

\section{Fecal Sampling and Analysis for Diet Estimation}

Dicts were estimated by determining species composition of epidermal fragments in the feces. This method has the advantage of allowing collection of a representative sample of plant species ingested by many animals integrated over a number of days without interfering with animal behaviour. Its main disadvantage is a built in bias that stems from differences in specific leaf area and epidermal erodibility during the digestion process (Bartolomé et al. 1995, Holechek et al. 1982). Forbs, in particular, tend to be underestimated.

Fecal samples were taken once every month between September 1988 and September 1989. At each sampling date, 10 to 20 separate samples of fresh fecal pellets in each flock were taken in the morning from about $10 \%$ of the sheep and goats. These samples were put in a freezer within 5 hours after collection and kept there until used for slide preparation. After thawing, 2 composite samples were made up, 1 of sheep pellets and 1 of goat pellets from each collection period and each flock. These were washed to remove extraneous material and then lightly ground in a mortar to separate out the epidermal fragments. From each composite sample, $10 \mathrm{~g}$ were placed in a test-tube with $5 \mathrm{ml}$ of concentrated $\mathrm{HNO}_{3}$ (Croker 1959, Stewart 1967, Chapuis 1980, Garcia-Gonzalez 1984). Nitric acid $\left(\mathrm{HNO}_{3}\right)$ was used instead of $\mathrm{NaOH}$ (Gross et al. 1983, Holechek and Gross 1982, 
Vavra and Holechek 1980) because it gave a more complete digestion of non-epidermal tissue (R. Garcia-Gonzalez, personal communication). Test-tubes were placed for 1 minute in a bath of boiling water and samples were diluted with $200 \mathrm{ml}$ of water. This suspension was then passed through $1.00 \mathrm{~mm}$ and $0.25 \mathrm{~mm}$ filters (Sparks and Malachek 1968, Garcia-Gunzalez 1984). The 0.25 to $1.00 \mathrm{~mm}$ fraction was dispersed in $50 \%$ aqueous solution of glycerin. Samples of the suspension were spread on glass microscope slides to give a density that precluded any significant overlapping of fragments and left to dry overnight. Cover-slips $(24 \times 60 \mathrm{~mm})$ were then fixed to the slides with DPX microhistological varnish. Five slides were prepared from each composite sample.

\section{Fragment Identification}

Slides were examined under microscope at $100 \mathrm{x}$ magnification by viewing traverses, $2 \mathrm{~mm}$ wide and $60 \mathrm{~mm}$ long with $3 \mathrm{~mm}$ between traverses. All fragments in each traverse were recorded and counted until 400 fragments of leaf epidermis were identified from each sample. A key prepared by J. Bartolomé (1991) was used to identify epidermal fragments. The observer was trained by identifying replicates of several samples which were not recorded. Unidentifiable leaf fragments were less than $1 \%$. Epidermal fragments of floral parts, stems, petioles, and midribs were not registered because of the difficulty in identifying the species of these fragments.

\section{Preference Index}

Preference or rejection of a vegetation component is commonly expressed as a function of its occurrence in the diet and its availability to the herbivore (Crawley 1983, Westoby 1974, Belovsky 1981). Availability in the present study was estimated as the vegetation composition accessible to the grazing animal weighted for the area of the different range or vegetation types (physiognomical group) and the time spent in each type. During the summer grazing period, soon after the vegetation composition was determined (in June-July), the flocks spent approximately twice the number of grazing hours on the heath and grassland than in the woodland. This was also taken into account when calculating average availability $\mathrm{V}^{\prime}{ }_{i k}$ of each vegetation component on each range unit farm):

$$
\mathrm{V}_{i k}^{\prime}=\frac{\mathrm{V}_{i k j} \cdot A_{j k} \cdot T_{j}}{\sum\left(\mathrm{V}_{i k j} \cdot A_{j k} \cdot T_{j}\right)}
$$

where,

$\mathrm{V}_{i k j}$ is the \% cover of the vegetation component $i$, on range type $j$, on range unit $k$

$A_{j k}$ is the area of range type $j$, on range unit $k$

$T_{j}$ is the ratio of time spent daily on the respective range types $\mathrm{j}$, in the months of June and July: $\mathrm{T}_{j}=1$ when $j=$ woodland, otherwise $\mathrm{T}_{j}=2$

Preference or aversion can then be estimated with an index, $S_{i k}$, like the lvlev electivity index (Ivlev 1961) for each vegetation component, $i$, on each range unit, $k$.

$$
\mathrm{S}_{i k}=\frac{\mathrm{D}_{i k}-\mathrm{V}_{i k}^{\prime}}{\mathrm{D}_{i k}+\mathrm{V}_{i k}^{\prime}}
$$

where, $\mathrm{D}_{i k}$ is the proportion of the component in the diet (during the summer months when the vegetation was sampled). The index indicates rejection when $\mathrm{S}_{i k}>0$.

\section{Diet Overlap}

Overlap of a species $i$ in the diets of sheep, $D_{i s}$, and goats, $D_{i g}$, can be expressed as an index, $L_{i}$, ranging between 0 and 1 :

$$
\mathrm{L}_{i}=1-\frac{\left|\mathrm{D}_{i s}-\mathrm{D}_{i g}\right|}{\left|\mathrm{D}_{i s^{-}}+\mathrm{D}^{\prime}{ }_{i g}\right|}
$$

The overlap between diets of sheep and goats, $\mathrm{L}$ can then be written as:

$$
\mathrm{L}=1-\frac{\sum_{i}\left|\mathrm{D}_{i s}-\mathrm{D}_{i g}\right|}{\sum_{i}\left|\mathrm{D}_{i s^{-}}+\mathrm{D}^{\prime}{ }_{i g}\right|}
$$

This is equivalent to the commonly used Kulczynsky similarity index (Oostin 1958).

\section{Chemical Analysis}

Chemical composition of the leaves of the more common plant species was determined to identify nutritive factors that may influence species selection. Three replicates of plant material were sampled at random sites, dried at $60^{\circ} \mathrm{C}$ and ground to pass through a $1 \mathrm{~mm}$ screen. Samples were analysed in triplicate. Dry matter (DM) was determined by drying at $103 \pm 1^{\circ} \mathrm{C}$ for 24 hours and crude protein calculated as $\mathrm{N} \times 6.25$. by the Kjeldahl procedure on a Kjeltec Auto 1030 Analyser (Tecator) according to AOAC (1984). Neutral detergent fibre (NDF), acid detergent fibre (ADF) and acid detergent lignin (ADL) were determined by the method of Goering and Van Soest (1970) on a Fibertec 1030 hot extractor (Tecator) and recorded as cell content (NDF-ADF), hemicellulose (DM-NDF) and lignin.

\section{Statistical Analysis}

The numbers of leaf epidermal fragments of each species were converted to percentages and subjected to arcsin (angular) transformation (Sokal and Rohlf 1969) before statistical analysis Allocation of total sum of squares between factors was determined by analysis of variance using SuperANOVA (Gagnon et al. 1990). Significant differences were determined by means of the Fischer Protected LSD method (Fischer 1949).

Epidermal fragments were of species that were selected by the animals, and so rejected or highly non-preferred species are not represented in the following analyses. Three factors that could influence the composition of epidermal fragments were considered: animal species (sheep, goats); season [defined as six, 2 month periods: early winter (December-January), winter (February-March), spring (April-May), early summer (June-July), summer (August-September), autumn (October-November)]; and flock or range unit ( 3 flocks, each grazing its own range unit). These 3 factors are orthogonal, so that the variance allocation to each is a true reflection of its contribution to the total accounted for variance $\left(R^{2}\right)$. The variance of the total of 72 diet estimates -6 periods ( 2 samples each period) $X$ 3 flocks $\times 2$ animal species-was analyzed as follows:

$\begin{array}{ll}\text { Source } & \text { d.f. } \\ \text { Flock } & 2 \\ \text { Animal sp. } & 1 \\ \text { Season } & 5 \\ \text { Flock } \times \text { Animal sp. } & 2 \\ \text { Flock } \times \text { Season } & 10\end{array}$


Flock $\times$ Season

Animal sp. $X$ Season

10

Flock $\times$ Animal sp. $\times$ Season $\quad 10$

Error

36

Total

71

\section{Results}

Over the whole annual cycle, a total of 111 species were identified in fecal samples, 87 of which were found in samples from sheep and 95 from goats; 71 species occurred in both sheep and goat feces. Only 23 species occurred in amounts of at least $1 \%$ of the total number of fragments in the feces of either sheep or goats. These 23 species accounted for 90 to $95 \%$ of the fragments (Table 2). While there are no considerable differences in species composition of the diets between flocks, all the listed species in Table 2 occur in all 3 flocks of both sheep and goats, indicating a considerable degree of similarity between sites and overlap between sheep and goat diets. The woody species are the most important component in the diets of both sheep and goats but much more so in the case of goats. The forbs were the smallest fraction of diets, but there may be a considerable negative bias in their estimate because of their more fragile epidermal layers (Bartolomé et al. 1995, Holechek et al. 1982).

Quercus ilex, Erica arborea, Calluna vulgaris, and Festuca spp. each constituted more than $10 \%$ in either sheep or goat diets. Thus, diet data were aggregated for analysis into the following components: Quercus, Erica arborea; Calluna; other woody species; Festuca; other graminoids; and forbs (Table 3).

Differences in fragment composition due to the animal factor were highly significant for all vegetative components (Table 3 ). This was the dominant factor in determining variance in total woody component (or in the complementary non-woody component), in Quercus ilex, in other woody species, and in the graminoid species, (53 to $60 \%$ of the total sum of squares). However, for the heath shrubs, and even to a greater degree for the nongramineous forbs, the period of the year accounted for more variance than differences between animal species. On the whole, differences between flocks were much smaller but usually significant. On the other hand, there were very few significant

Table 2. Average annual species composition of epidermal fragments in feces of 3 mixed herds of sheep and goats grazing in 3 farms in the Montseny Biosphere Reserve, Catalunya, Spain (1989/90).

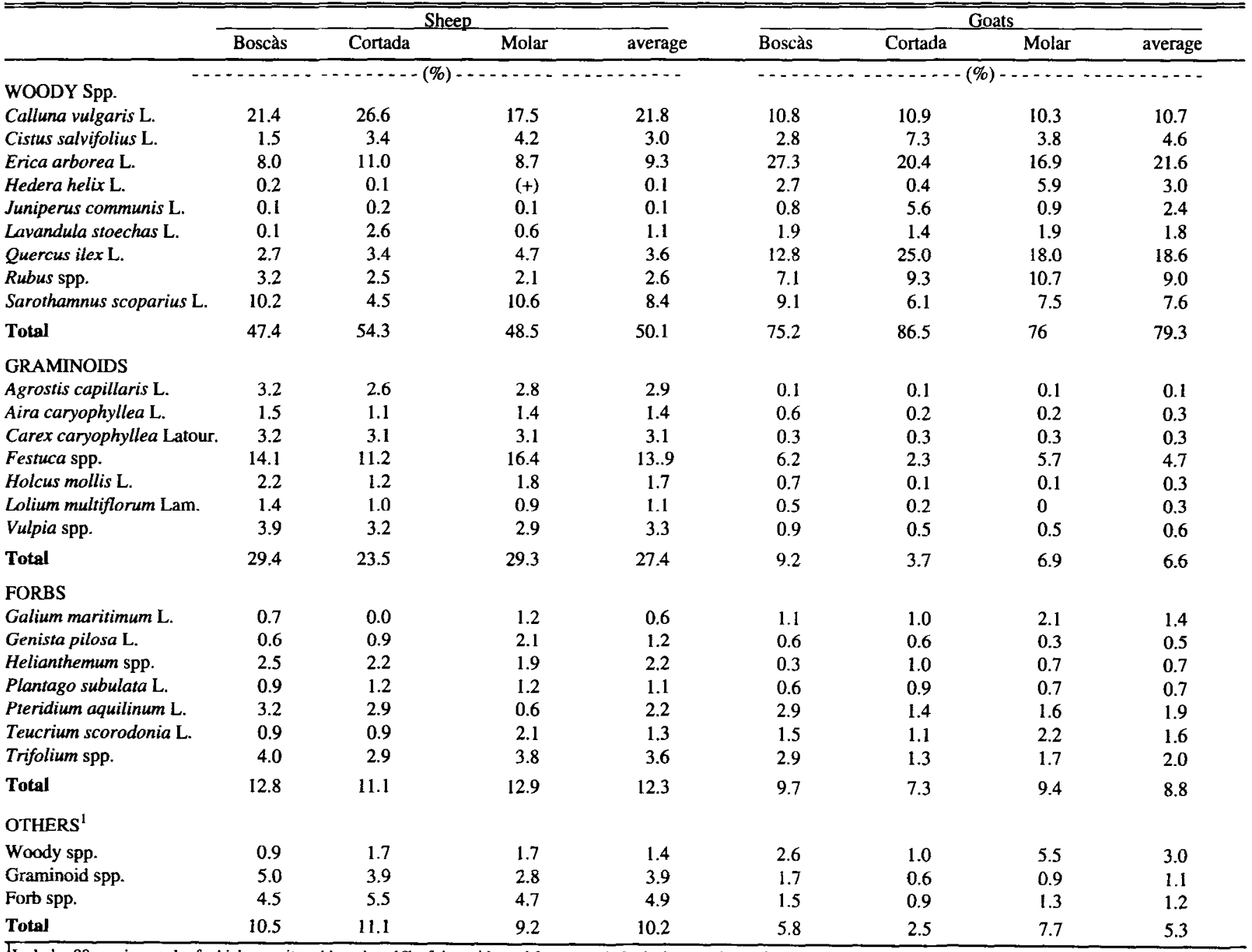

Includes 88 species, each of which constituted less than $1 \%$ of the epidermal fragments in both sheep and goat fecal samples. $(+)<0.1$ 


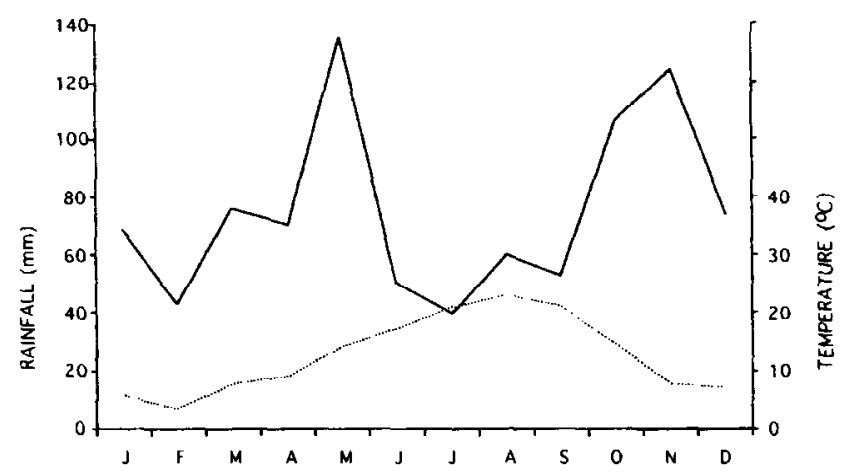

Fig. 1. Climate diagram for the El Vilar de la Castanya station (700 $m$ a.s.l.) in the Montseny Biosphere Reserve. Temperature monthly mean for years 1985 to 1988 . Rainfall monthly means for years 1983 to 1992. Temperature $\left({ }^{\circ} \mathrm{C}\right) \ldots$

interactions between factors, the most noteworthy being those between animal species $X$ period, in the cases of Calluna and Quercus: Calluna varied with season more in goats than in sheep, while Quercus was consumed by sheep mainly in the winter and in much smaller amounts than goats (Figs. 2 and 3). Significant factors, including significant interactions, accounted for $68 \%$ to $87 \%$ of total variation in fragment composition in the different components, leaving up to $32 \%$ unexplained variance.

In accordance with previous studies (Leclerc 1985, Howe et al. 1988, Bullock 1985, Bryant et al. 1979), goats selected mainly woody species while sheep selected both woody and herbaceous species more or less to the same degree. There were also large differences within the group of woody species selected (Table 2). All vegetation components in diets varied with season of the year but some more than others (Fig. 2 and 3). The proportion of Calluna vulgaris peaked in late summer to winter, and then dropped to lower levels in the summer and autumn. Forbs and 'other graminoid species' fluctuated within a narrower band that peaked in the winter and dipped in the summer. Festuca remained fairly constant throughout the year.

The site factor was notable especially in the Cortada flock where the proportion of woody species in diet was highest (Table 2 ). This could have been caused by the greater proportion of woodland on the Cortada site (Table 1) where availability of Quercus ilex was high, while the availability of herbaceous species (including forbs) was correspondingly lower.

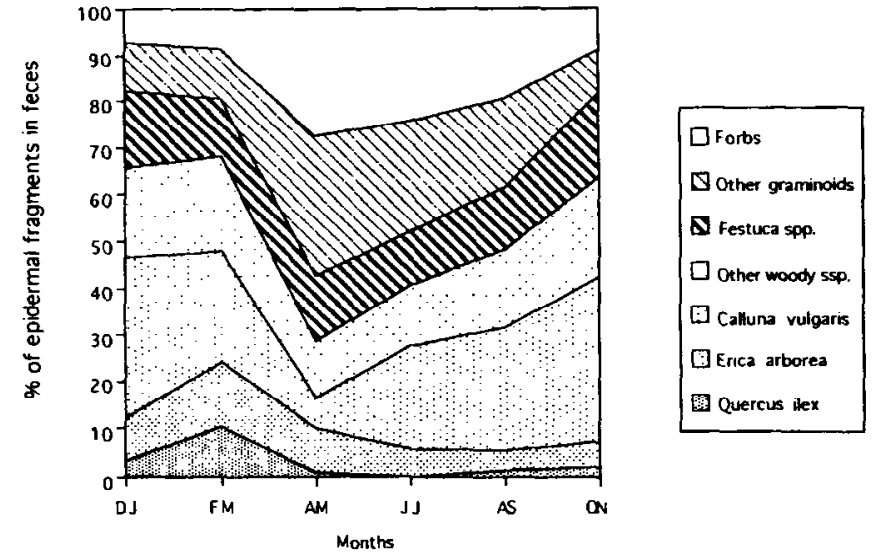

Fig. 2 Annual diets of 3 sheep flocks grazing a mixed woodland/shrubland range.

Interactions between animals and season relate mainly to Calluna and to Quercus (Table 3). Calluna is a major component in the diets of sheep in winter (Fig. 2) when it is a minor component of the diets of goats (Fig. 3). It is a low shrub, easily grazed by the sheep and is green in winter when there are few other alternative feed sources. Quercus is a negligible component of sheep diets except in winter, while it is an important component of goats' diets throughout the year. Even when the flocks are based on the altiplano, the goats voluntarily entered the woodland to browse. In the summer, the sheep entered the woodland only for shade during the hot hours of the day, but did not browse, possibly because the young green Quercus leaves were too high to be comfortably grazed by animals that tend to graze with their head down.

The Ivlev electivity index shows that the rejection rating of Quercus by sheep is very high (Fig. 4). Of the other components, Festuca and other graminoids, tend to be preferred by sheep and avoided by goats. Erica arborea is preferred by both animals, and forbs are lightly avoided by goats. Calluna and other woody species are more or less indifferent. These preferences cannot be generalized because preferences depend on the available choice of feed items. Other studies have produced different results. Clark et al. (1982) found that grasses werc taken preferentially by both sheep and goats while clovers were preferentially grazed by sheep.

Table 3. Allocation of variation in composition of epidermal fragments in feces between factors. Percent of total sum of squares calculated for each vegetation component separately.

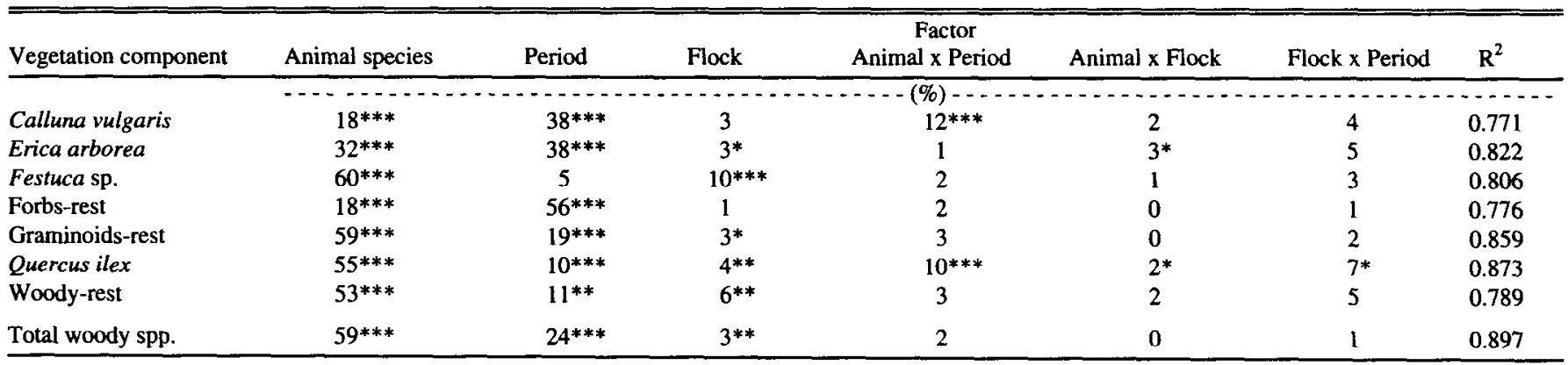

${ }^{*} \mathrm{p}<.05,{ }^{* *} \mathrm{P}<.01,{ }^{* * *} \mathrm{p}<.001$ 
Table 4. Mean chemical composition of leaves of browse and grass species in the experimental site in late spring, 1990.

\begin{tabular}{lccccc}
\hline \hline Species & Crude Protein & Cell content & Cellulose & Hemicellulose & Lignin \\
\hline & $-\ldots \ldots$ & $23.4 \pm 0.8$ & $17.0 \pm 0.9$ & $12.9 \pm 2.1$ \\
Quercus ilex & $11.9 \pm 0.72$ & $46.7 \pm 3.3$ & $12.4 \pm 0.7$ & $12.1 \pm 0.7$ & $31.5 \pm 1.8$ \\
Erica arborea & $8.9 \pm 0.62$ & $44.0 \pm 2.2$ & $15.6 \pm 0.7$ & $12.1 \pm 0.6$ & $17.8 \pm 1.2$ \\
Calluna vulgaris & $8.0 \pm 0.52$ & $54.6 \pm 1.1$ & $31.9 \pm 1.0$ & $36.5 \pm 1.2$ & $5.4 \pm 0.9$ \\
Festuca ovina & $8.0 \pm 0.42$ & $26.2 \pm 0.8$ & & \\
\hline
\end{tabular}

Mean \pm SD

Compared to graminoids, the main browse species had higher soluble cell content and slightly higher protein content, but much higher lignin content (Table 4). High lignin in goat diets elicited the hypothesis that goats may have a special mechanism that can attenuate the undesirable effect of excess lignin (Howe et al. 1988). But whatever the mechanism, there is a tradeoff between the nutritional and anti-nutritional factors in the browse so that even the sheep consume it to a large extent.

\section{Discussion}

Seasonal fluctuations in diets occur, but aggregation of diets throughout the year gives an assessment of resource utilization. Selection is primarily constrained by the species composition of the vegetation communities on the respective rangeland units, but within a community very different diets can be composed. The separate effects of availability and selection can be considered in greater detail to identify reasons for the differences (and similarities) in foraging behaviour.

From Table 2 we can conclude that, faced with similar opportunities for choice, sheep and goats on the whole select fairly similar species, but in different proportions. The dietary differences appear to follow from differences in foraging behavior. Goats were more agile and foraged with their heads raised while sheep tended to graze with less movement and with their heads down. This behavioral difference gave the goats an advantage in prehending more attractive but less accessible feed items in the woody vegetation while the sheep favored the feed items on the lower herbaceous vegetation.
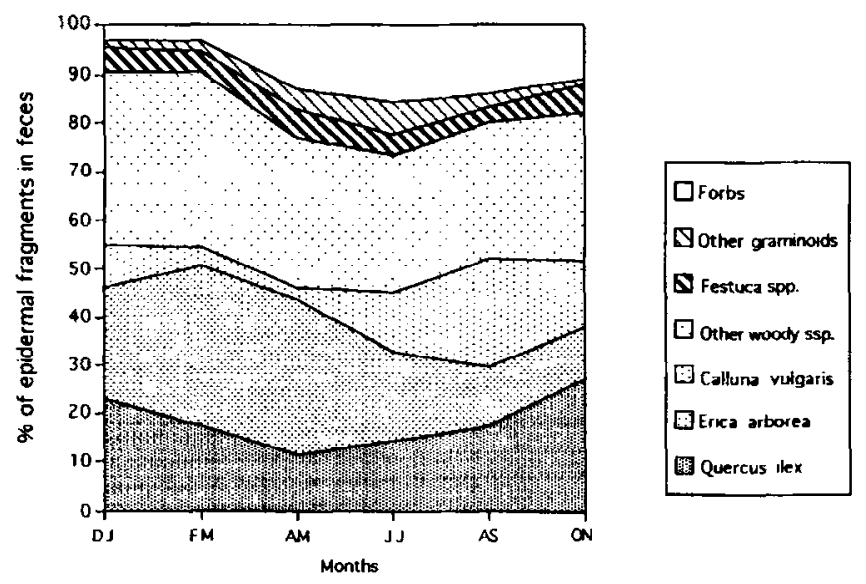

Fig. 3. Annual diets of 3 goat herds grazing a mixed woodland/shrubland range.
The animals in this study behaved as opportunistic foragers with different foraging styles. Within a large group of acceptable species, they did not seem to fine-tune their species preferences. They did not exhibit exceptional botanical discrimination and apparently did not need to because their selection criteria, the 'currency' that concerns them (Stephens and Krebs 1988), cuts across many species at more or less equivalent phenological stages.

Woody species and graminoids are, on the whole, spatially separated into woodland and heathland-grassland communities that occur in different proportions in the different rangeland units (Table 1). As commonly observed woody species are more prominent in the goat diet and graminoids in the sheep diet (Table 2 ), but despite the differences, these species groups in both sheep and goat diets are related with their availability in the rangeland units (Fig. 4). The fact that the flocks grazed together meant that they spent similar periods in the different vegetation types but they still selected different diets. The high correlation between the occurrence of the main species groups in the sheep and goat diets (Table 5) reflects the fact that both sheep and goats selected according to the availability of these groups among the different rangeland units. Within these groups, difference in foraging behaviour became dominant. Consequently, correlation between sheep and goat intake of individual species varied over the whole range from highly positive to highly negative.

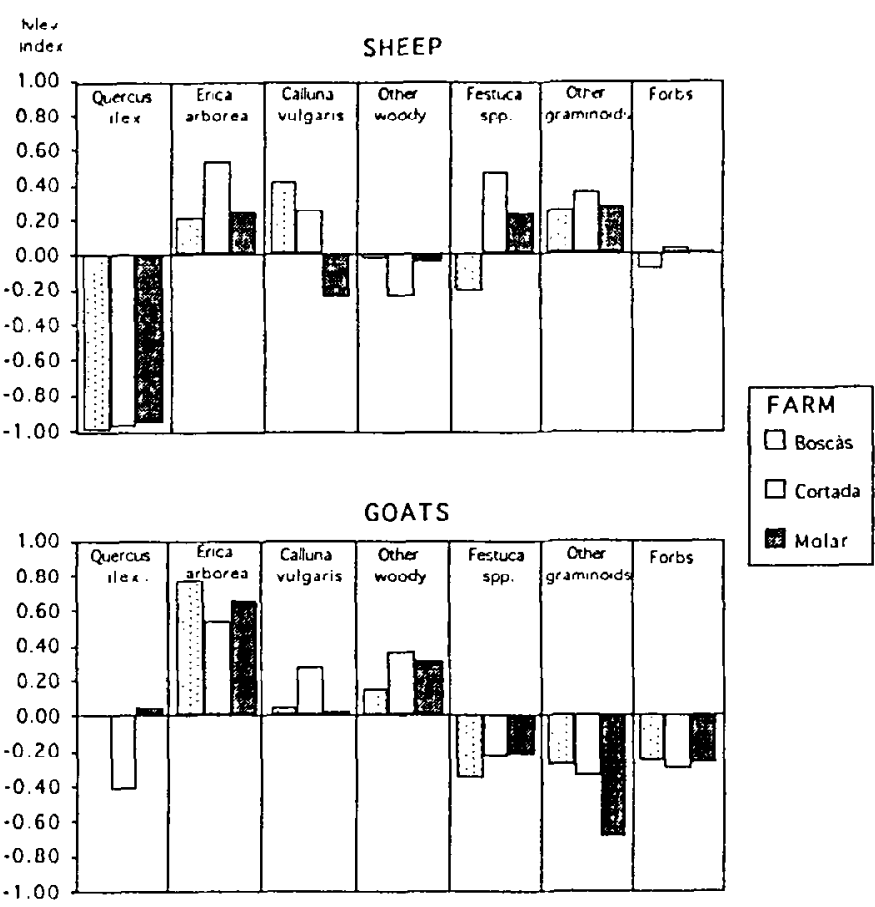

Fig. 4. Preference/aversion by sheep and goats of major vegetative components of the range. 


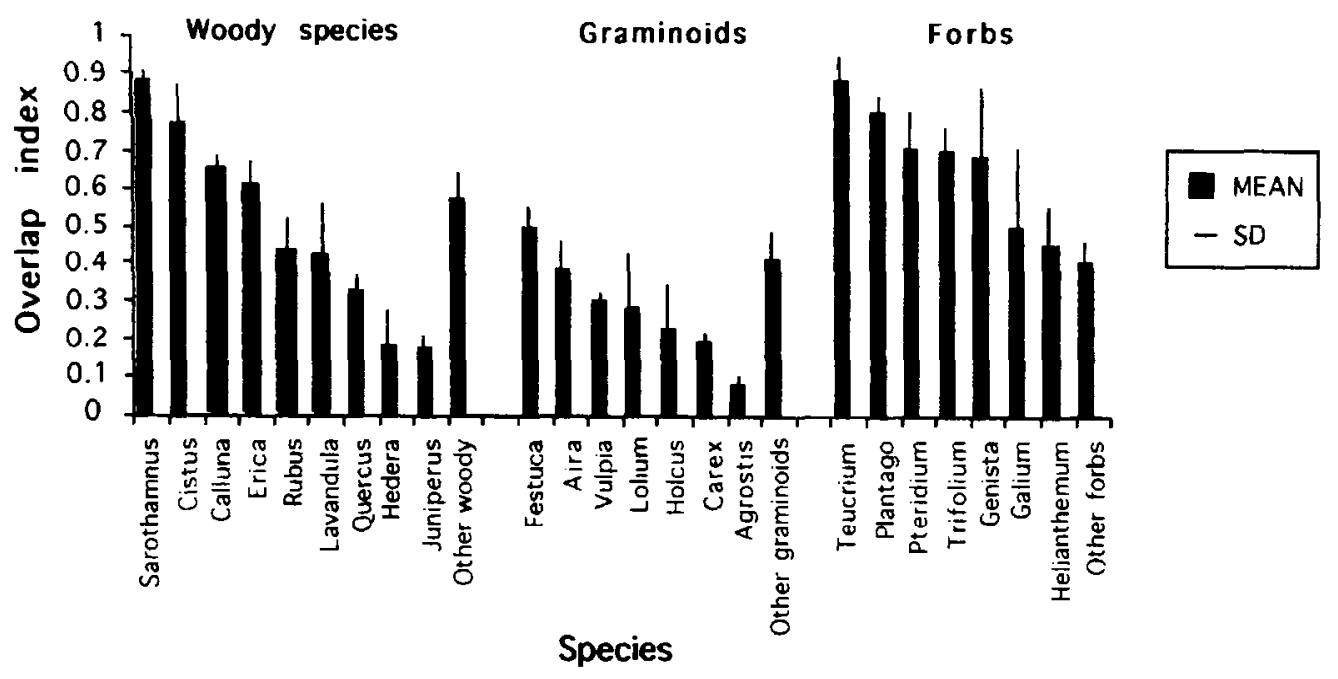

Fig. 5. Species overlap between the diets of sheep and goats grazing in mixed flocks. Mean and standard deviation of overlap indices of 3 farms.

The diets of the goats were more closely related to availability of major species than those of the sheep (Fig. 4). This suggests that the goats in this study were less selective than the sheep. Although the proportion of graminoids, and especially Festuca in the goat diet was closely related to their availability, they were a minor component compared to that of the sheep (Table 2), possibly because the goat preference for browse led them to tarry longer in the woodland than the sheep whenever there was an opportunity. Such opportunities arose when the flocks were in the transition zones between the woodland and the heathland on the altiplano and were of sufficient duration for the goats to ingest about double the amount of forage from woodland browse species. These included Quercus ilex, Erica arborea, Hedera helix, Rubus sp. (Table 2). Among the woodland species, $Q$. ilex appeared most frequently in the goat diet and was closely related to its availability (Fig. 4). E. arborea, was prominent in the diet (Table 2) and by the Ivlev electivity index would be regarded as a preferred species (Fig. 4) even though it seems inferior to $Q$. ilex by standard nutritional criteria (Table 4). On the rangeland unit where there was less $Q$. ilex, intake of $E$. arborea by goats was higher despite its low availability. On the other hand, where $E$. arborea was most abundant (Molar farm), it constituted the lowest proportion in the goat diet (Table 2). It seems as if selection of $E$. arborea was contingent on the availability of $Q$. ilex, possibly as a consequence of the lower lignin content of $Q$. ilex leaves.
Erica scoparia, which is a prominent component of the heath vegetation, was completely avoided by both sheep and goats. In winter, when the herbaceous vegetation was sparse, the sheep selected $Q$. ilex even though they avoided it for the rest of the year. When little else is available, selection of woody species by sheep in winter is not unusual (Posse et al. 1996).

The lower occurrence of browse species associated with the heathland, like Calluna vulgaris and Sarothamnus scoparius in the goat compared to the sheep diet seems to be related to the relatively shorter time the goats spent on the heathland. However, both sheep and goats were heavy browsers on the heathland, although the sheep did select relatively more graminoids (Table 2).

There was moderate overlap of woody species and forbs in sheep and goat diets and lower overlap of graminoids (Fig. 5). The values are similar to those obtained in other studies (Martinez 1988, Bullock 1985, Bryant et al. 1980) and similar to the overlap between cattle and elk in different habitats (Kingery et al. 1996). Among the individual plant species, there is much variation with high overlap mainly between the species that dominate the diet. In other words, sheep and goats grazing together do exploit the vegetation differently, but there is also considerable utilisation of similar resources and potential competition for them.

With optimization of species selection at the bite level most unlikely (Illius and Gordon 1990), the animals need a realistic

Table 5. Correlation between mean annual species occurrence in the diets of sheep and goats in 3 flocks (sheep/goats).

\begin{tabular}{|c|c|c|c|c|c|}
\hline Woody spp & I & Graminoids spp & $\overline{\mathbf{r}}$ & Forbs spp & $\bar{\Gamma}$ \\
\hline Juniperus communis & 1.00 & Lolium multiflorum & 0.98 & Teucrium scorodonia & 0.93 \\
\hline Calluna vulgaris & 0.90 & Vulpia spp. & 0.96 & Galium maritimum & 0.86 \\
\hline Sarothamnus scoparius & 0.81 & Festuca spp. & 0.84 & Trifolium spp. & 0.81 \\
\hline Cistus salvifolius & 0.43 & Holcus mollis & 0.80 & Plantago subulata & 0.76 \\
\hline Quercus ilex & 0.26 & Aira caryophyllea & 0.69 & Pteridium aquilinum & 0.48 \\
\hline Erica arborea & -0.40 & Agrostis capillaris & 0.00 & Helianthemum spp. & -0.57 \\
\hline Hedera helix & -0.58 & & & Genista pilosa & -0.98 \\
\hline Lavandula stoechas & -0.98 & & & & \\
\hline Rubus spp. & -1.00 & & & & \\
\hline Woody spp & 0.99 & Graminoids spp & 0.99 & Forbs spp & 0.90 \\
\hline
\end{tabular}


'rule of thumb' (Cassini 1994, Wallis de Vries and Schippers 1994) to guide foraging behaviour that can ensure efficient utilisation of foraging time, even though it could never be mathematically optimal. Such a rule could be something like "keep moving until satiety and select from among whatever is immediately available, choose the greener, less coarse, bigger item unless it has a perceptible objectionable attribute". A marginal value threshold could conceivably control rate of movement from one 'feeding station' to the next (Stephens an Krebs 1988, Stuth 1990) and signal 'operational satiety'. By this criterion it seems inevitable that many choices in a mixed species, continually changing pasture must be sampling choices (Westoby 1978) or random choices between alternatives that are too similar of the trade-offs too complex for the animal to make a clear distinction between them. Diet prediction at the species level based on optimal foraging theory is therefore unlikely to be reliable in any but simple cases (Belovsky 1981, Owen-Smith and Novellie 1982, Owen-Smith 1993). Diet prediction at the level of a very small number of major species groups (or 'food classes') with similar preference attributes has been shown to be more tractable (Belovsky 1984).

\section{Conclusion}

From this study we can conclude that, faced with similar opportunities for choice, sheep and goats on the whole select fairly similar species, but in different proportions. The animals behaved as opportunistic foragers with different foraging styles. Within a large group of acceptable species, they did not seem to fine-tune their species preferences. They did not exhibit exceptional botanical discrimination and apparently did not need to distinguish between many species with similar nutritional value at more or less equivalent phenological stages.

\section{Literature Cited}

A.O.A.C. 1984. Official Methods of Analysis. Association of Official Analytical Chemists. 14th Ed., Arlington Va.

Bartolomé, J. and J. Franch. 1992. An archaic grazing system in the N.E. of Spain, p. 80-86. MEDECOS VI, Proceedings of the 6th International Conference on Mediterranean Climate Ecosystems. Univ of Athens, Greece.

Bartolomé, J. 1991. Clave de determinación de epidermis foliares de la zona de La Calma (Montseny). Thesis, Autonomous University of Barcelona, Spain.

Bartolomé, J. and J. Franch, M. Gutman, and N.G. Seligman 1995. Physical factors that influence fecal analysis estimates of herbivore diets. J. Range Manage. 48:267-270.

Belovsky, G.E. 1981. Food plants selection by a generalist herbivore, the moose. Ecol. 62:1020-1030.

Belovsky, G.E. 1984. Herbivore optimal foraging, a comparative test of three models. The Amer. Natur. 129:97-115.

Bolòs, O. de 1983. La Vegetació del Montseny. Diputació de Barcelona, Servei de Parcs Naturals, Barcelona.

Bryant, F.C., M.M. Kothmann, and L.B. Merrill. 1979. Diets of sheep, goat, and white-tailed deer diets on excellent condition rangeland in Texas. J. Range Manage. 32:412-417.

Bryant, F.C., M.M. Kothmann, and L.B. Merrill. 1980. Nutritive content of sheep, goat, and white-tailed deer diets on excellent condition rangeland in Texas. J. Range Manage. 33:410-414.

Bullock, D.J. 1985. Annual diets of hill sheep and feral goats in southern Scotland. J. Appl. Ecol. 22:423-433.
Cassini, M.H. 1994. Behavioural mechanisms of selection of diet components and their ecological implications in herbivorous mammals. J. of Mammology. 75:733-740.

Chapuis, J.L. 1980. Méthodes d'étude du régime alimentaire de Lapin de garenne (Oryctolagus cuniculus L.) par l'analyse micrographique des feces. Revue. Ecologie (La Terre et la Vie) 34:159-198.

Clark, D.A., M.G. Lambert, M.P. Ralston, N. Dymock. 1982. Diet selection by goats and sheep on hill country. Proc. New Zealand Soc. Anim. Prod. 42:155-157.

Crawley, M.J. 1983. Herbivory: The Dynamics of Animal-plant Interactions. Studies in Ecology, Volume 10. Blackwell Scientific Publ., Oxford, U.K

Croker, B.H. 1959. A method of estimating the botanical composition of the diet of sheep. New Zealand J. Agr. Res. 2:72-85.

Cuartas, P. 1992. Herbivorismo de grandes mamíferos en un ecosistema de montaña mediterránea. Ph.D. Thesis, Univ. of Oviedo.

Cuartas, P. and R. García-González. 1992. Quercus ilex browse utilization by Caprini in Sierra de Cazorla and Segura (Spain). Vegetatio 99-100:317-330.

Fedele, V., M. Pizzillo, S. Claps, P. Morand-Fehr, and R. Rubino. 1993. Grazing behaviour and diet selection of goats on native pasture in southern Italy. Small Ruminant Res. 11:305-322.

Fischer, R.A. 1949. The Design of Experiments. Oliver \& Boyd, Edinburg, U.K.

Gagon, J., K.A. Haycock, J.M. Roth, D.S. Feldman, W.F. Finzer, R. Hofmann, and J. Simpson. 1990. SuperANOVA. Accessible General Linear Modeling. Abacus Concepts, Inc., Berkeley, Calif.

García-González, R. 1984. L'emploi des epidermes végétaux dans la détermination du régime alimentaire de l'lsard dans les Pyrénées occidentales. Écologie des milieux montagnards et de haute altitude. Documents d'Écologie Pyrénéenne III-IV:307-313.

Goering, H.K. and J.P. Van Soest. 1970. Forage Fiber Analyses. USDA Handb. 379:20.

Gross, B.D., E. Mahgoub, J.L. Holechek. 1983. Mastication effects on cattle diet determined by microghistological analysis. J. Range Manage. 36:475-476.

Holechek, J.L. and B.D. Gross. 1982. Training needed for quantifying simulated diets from fragmented range plants. J. Range Manage. 35:644-647.

Holechek, J.L. M. Vavra, and R.D. Pieper. 1982. Botanical composition determination of range herbivore diets. A review. J. Range Manage. 35:309-315.

Howe, J.C., T.N. Barry, and A.I. Popay. 1988. Volutary intake and digestion of gorse (Ulex europaeus) by goats and sheep. J. of Agr. Sci. (Cambridge) 111:07-114.

Illius, A.W. and I.J. Gordon. 1990. Constraints on Diet Selection and Foraging Behaviour in Mammalian Herbivores, p. 369-393. In: Hughes, R.N. (ed.), Behavioural Mechanisms of Food Selection. Springer Verlag, Berlin.

Ivlev, V.S. 1961. Experimental Ecology of the Feeding Fishes. Yale Univ. Press, New Haven.

Kingery, J.L., J.C. Mosley, and K.C. Bordwell. 1996. Dietary overlap among cattle and cervids in northem Idaho forests. J. Range Manage. 49:8-15.

Leclerc, B. 1985. Utilisation du maquis corse par des caprins et des ovins. Acta OEcological/OEcologia Applicata 6:303-314.

Leoufre, M.C. E. Lecrivain, and B. Leclerc. 1989. Consommation par des caprins de Quercus ilex et Quercus pubescens dans un taillis mediterraneen. XVI Congres International des Herbages, Nice, France. 1083-1084.

Martinez, T. 1988. Comparacion de los habitos alimentarios de la cabra montes y de la oveja en la zona alpina de Sierra Nevada. Archivos de Zootecnia 137:39-49.

Oosting, H.J. 1958. The Study of Plant Communities. W.H. Freeman and Company. San Francisco, 440 pp.

Owen-Smith. N. 1993. Evaluating optimal diet models for an African browsing ruminant, the kudu, how constraining are the assumed constaints. Evolutionary Ecol. 7:499-524.

Owen-Smith, N. 1994. Foraging responses of kudus to seasonal changes in food resources: Elasticity in constraints. Ecol. 75:1050-1062. 
Owen-Smith, N. and P. Novellie. 1982. What should a clever ungulate eat? The Amer. Natur. 119:151-178.

Pfister, J.A. and J.C. Malachek. 1984. The voluntary forage intake and nutrition of goats and sheep in the semi-arid tropics of north-eastern Brazil. J. Anim. Sci. 63:1078-1086.

Pfister, J.A. J.C. Malachek, D.B. Balph. 1988. Foraging behavior of goats and sheep in the Caatinga of Brazil. J. Appl. Ecol. 25:379-388.

Posse, G., J. Anchorena, and M.B. Collantes. 1996. Seasonal diets of sheep in the steppe region of Tierra de Fuego, Argentina. J. Range Manage. 49:24-30.

Provenza, F.D. 1994. Ontogeny and Social Transmission of Food Selection in Domesticated Ruminants, p. 147-164. In: Galef Jr., B.G. Mainardi, M. and Valsecchi, P., Behavioral Aspects of Feeding-Basic and Applied Research in Mammals. Ilarwood Acad. Publ., Singapore.

Sokal, R.R. and F.J. Rohlf. 1969. Biometry. W.H. Freeman and Company. San Francisco, Calif.

Sparks, D.R. and J.C. Malechek. 1968. Estimating percentage dry weight in diets using a microscopic technique. J. Range Manage. 21:264-265.

Stephens, D.W. and J.R. Krebs. 1988. Foraging Theory. Princeton University Press, Princeton, N.J.

Stewart, D.R.M. 1967. Analysis of plant epidermis in faeces, a technique for studying the food preferences of grazing herbivores. J. Appl. Ecol. 4:83-111.
Stuth, J.W. 1990. Foraging Behavior, p. 65-83. In: Heitschmidt, R.K and Stuth, J.W. (eds.), Grazing Management-An Ecological Perspective. Timber Press Inc., Portland, Ore.

Vavra, M.V. and J.L. Holechek. 1980. Factors influencing Microhistological Analysis of Herbivore Diets. J. Range Manage. 33:371-374

Wallis de Vries, M.F. and P. Schippers. 1994. Foraging in a landscape mosaic: selection for energy and minerals in free-ranging cattle. Oecologia 100:107-117.

Warren, L.E., D.N. Ueckert, and J.M. Shelton. 1984. Comparative diets of Rambouillet, Barbado and Karakul sheep and Spanish and Angora goats. J. Range Manage. 37:172-180.

Westoby, M. 1974. An analysis of diet selection by large generalist herbivores. The Amer. Natur. 108:290-304.

Westoby, M. 1978. What are the biological bases of varied diets? The Amer. Natur. 112:627-631.

Wilson, A.D., J.H. Leigh, N.L. Hindley, and W.E. Mulham. 1975. Comparison of the diets of goats and sheep on a Casuarina cristata-Heterodendrum oleifolium woodland community in western New South Wales. Austr. J. Exp. Agr. and Anim. Husb. 15:45-53.

\section{Associate Editor Nominations Journal of Range Management}

Replacements are needed for Associate Editors of the Journal of Range Management retiring from the Editorial Board in

Feb. 1999. We are seeking nominees with expertise in the following general subject areas:

animal physiology,

plant physiology,

plant ecology,

plant/animal interactions,

grazing management,

improvements,

measurement/sampling, and

soils.

Associate Editors serve for 2 years with an optional 2 additional years with the concurrence of the Editor, JRM. Each Associate Editor will oversee the technical review and revision of 10-15 manuscripts per year within their area of expertise. This will require each Associate Editor to select qualified peer reviewers that will provide timely and constructive reviews.

To nominate a candidate for this important and demanding position, ascertain that the individual is available and willing to serve and then send a letter of nomination to the Editor describing the nominee's qualifications. Interested individuals may nominate themselves. The candidate will be asked to supply a list of representative publications and an account of experience in reviewing manuscripts. It is desirable if the Associate Editor can oversee the technical reviews in at least 3 of the general subject areas.

Send nominations by 1 Aug. 1998 to: Gary Frasier, Editor, Journal of Range Management, 7820 Stag Hollow Road, Loveland, Colorado 80538.

Fax: 970-482-2909

E-mail gfrasier@lamar.colostate.edu or gfrasier@aol.com 